Article

\title{
Comparison of Radar-Based Hail Detection Using Single- and Dual-Polarization
}

\author{
Kateřina Skripniková * and Daniela Řezáčová \\ Institute of Atmospheric Physics, Czech Academy of Sciences, 14100 Prague, Czech Republic; rez@ufa.cas.cz \\ * Correspondence: skripka@ufa.cas.cz; Tel.: +420-272-016-016
}

Received: 15 May 2019; Accepted: 12 June 2019; Published: 17 June 2019

\begin{abstract}
The comparative analysis of radar-based hail detection methods presented here, uses C-band polarimetric radar data from Czech territory for 5 stormy days in May and June 2016. The 27 hail events were selected from hail reports of the European Severe Weather Database (ESWD) along with 21 heavy rain events. The hail detection results compared in this study were obtained using a criterion, which is based on single-polarization radar data and a technique, which uses dual-polarization radar data. Both techniques successfully detected large hail events in a similar way and showed a strong agreement. The hail detection, as applied to heavy rain events, indicated a weak enhancement of the number of false detected hail pixels via the dual-polarization hydrometeor classification. We also examined the performance of hail size detection from radar data using both single- and dual-polarization methods. Both the methods recognized events with large hail but could not select the reported events with maximum hail size (diameter above $4 \mathrm{~cm}$ ).
\end{abstract}

Keywords: hail detection; hailstone size; weather radar; single-polarization radar; dual-polarization radar

\section{Introduction}

Radar measurements using dual-polarization have become common in recent years following the upgrade of radar equipment by national weather services [1,2]. Measured polarimetric variables are sensitive to the shape, size, phase state and fall orientation of aloft hydrometeor particles. Compared with a single-polarization, polarimetric radar measurements provide more information for retrieving a cloud's microphysical structure. They are able to identify different microphysical categories $[3,4]$ including hail. Basically, the polarimetric hail detection is based on the differences in the radar cross sections for rain and hail particles at horizontal and vertical linear polarization [4].

Various hail detection methods based on single-polarization radar data were discussed in Reference [5], for example. Several of them were used to define a criterion designated COMBI, because of its definition, which combines the results of three partial hail detection criteria (see the Section 2.1 for the definition) [5]. In this study, we focus on comparing hail detection performance when using single- and dual-polarization data during identical hail events. The hail detection ability of the COMBI criterion [5] is compared with the results of Vaisala Hydrometeor Classification (HydroClass) [6]. In addition to hail occurrence detection, hail size detection is also compared here by using single-polarization [7] and dual-polarization [8] radar data.

Various hydrometeor classification methods using dual-polarization radar data were designed [9]. For evaluating a large set of dual-polarization variables, decision tree methods are possibly applied, which often use hard boundary values for polarimetric variables to discriminate between hydrometeor types [10,11]. However, as Vivekanandan [12] noted, using hard boundaries can lead to misclassification because of considerable overlap between polarimetric variables for diverse precipitation types. Fuzzy logic enables a smooth transition in polarimetric variable boundaries. Therefore, fuzzy methods for 
hydrometeor classification were proposed in previous studies [12,13]. The Vaisala HydroClass [6] contains a collection of echo identification algorithms and uses the fuzzy logic approach.

Another approach to hydrometeor classification is based on neural network techniques $[14,15]$. In the neural network scheme, the training essentially builds the system. A training set of considerable size is needed, which is often difficult to obtain [13]. Liu and Chandrasekar [15] proposed a neuro-fuzzy classification system, which is built by fuzzy logic definitions and is then improved by using neural network-type training.

The advantages of dual-polarization radars and their capability in hydrometeor classification have been described in various studies, for example, References [16,17]. Comparison of algorithms using single-polarization and dual-polarization radar data showed that the dual-polarization fuzzy logic hydrometeor classifier outperformed the single polarization probability of hail indicator during the Joint Polarization Experiment (JPOLE) [16]. JPOLE was a demonstration project for evaluating the performance of the U.S. weather radar network including dual polarization. Hail ground-truth data, included in the JPOLE, were collected by storm-intercept vehicles and comprised 47 reports from four hail events. It means that the verification ground data were able to get thorough information about the time and place changes in hail occurrence during the hail events. Two hail detection algorithms were applied. The conventional Hail Detection Algorithm (HDA), based on single polarization data [7], was compared with the results of the polarimetric hydrometeor classification algorithm (HCA). While the HDA characterizes a whole storm cell and does not specifies the actual location of the hail, the HCA determines precise regions of hail within a storm cell [16]. For the four cases, the HCA outperformed the HDA in terms of overall accuracy and skill. There was a 49\% increase in the Heidke Skill Score and a 33\% decrease in the probability of false detection when using dual-polarization hail classification.

The hail size discrimination algorithm [17] used horizontal reflectivity ( $\mathrm{Zh}$ ), differential reflectivity $(\mathrm{Zdr})$ and correlation coefficient $(\rho \mathrm{hv})$, along with melting level height, in a fuzzy logic scheme and quantifies the hail size better than the traditional single-polarization algorithm.

In this paper the results of the Vaisala HydroClass algorithm [6] are discussed and compared with COMBI approach. Both techniques differ fundamentally by the input data and also in their aims and adjustment to European events. The HydroClass technique is a general method, which aims at the classification of various hydrometeor types by using the set of polarization variables. On the other hand, the COMBI was developed specifically for hail detection only and tested with a set of European more or less local hail events.

The article is arranged as follows. After the introduction (Section 1), methods and data are described in Section 2. Polarimetric radar variables and used methods are summarized in Section 2.1. Hail reports and the other input data are described in Section 2.2. The Section 3 provides the results description. Section 3.1 compares the results of hail occurrence detection using both single- and dual-polarization data and the comparison of hailstone size is in Section 3.2. The concluding Section 4 summarizes the main results.

\section{Materials and Methods}

\subsection{Radar Variables and Methods}

Hail detection via conventional Doppler radars is based on a measurement of radar reflectivity at horizontal polarization. Volumetric radar measurements are often used in combination with atmospheric sounding data. The COMBI criterion for hail detection with single-polarization radar data was developed by Skripniková and Řezáčová [5]. It was defined by requiring that at least 1 of 3 basic hail detection criteria were met for the detection of hail occurrence. The three basic input criteria consisted of the Waldvogel criterion [18], the Severe Hail Index (SHI) [7] and the Probability of Severe Hail (POSH) [7]. The definitions of the three criteria and the necessary parameters needed by them are described in the study [5]. 
All these parameter values were optimized for the use in the COMBI criterion with the hail events and radar data from Czechia and SW Germany (see Figure 1 in Reference [5]). In the first step the parameters of Waldvogel, SHI and POSH were optimized individually with German hail damage data. The best parameter values were determined on the basis of well-known Critical Success Index. Starting from the selected individual values, and by using numerous combinations of parameters, the optimal combination was found. The resulting parameters for the COMBI criterion were slightly subjectively adjusted for use over the Czech territory. The resulting COMBI proved its ability in the detection of hail of about $2 \mathrm{~cm}$ in diameter [5]. In this study, the COMBI criterion is used to compare hail detection based on single-polarization and dual-polarization data.

In addition to hail occurrence detection, hail size detection is also compared using single- and dual-polarization radar data. For hail size detection with single-polarization radar data, the algorithm determining Maximum Expected Hail Size (MEHS) was applied. This hail-size model comes from the relationship between the SHI and hailstones size [7]. It uses the relation:

$$
\text { MEHS }=2.54(S H I)^{0.5}
$$

with MEHS given in millimeters. As the SHI was already available, we used the (1) for the comparative computation.

Dual-polarization radars provide values of several variables that can be used for hydrometeor classification. The Colorado State University (CSU) model, which is a basis of HydroClass software [6], uses five polarimetric input variables [19]. These are: reflectivity at horizontal polarization, differential reflectivity, specific differential phase, linear depolarization ratio and correlation coefficient. Moreover, the melting layer height is used. Radar observed variables and their usefulness in hail discrimination can be briefly characterized as follows (see also e.g., References [9,12]).

Reflectivity at a horizontal polarization $(\mathrm{Zh})$ is proportional to the received power of a horizontally polarized electric field from the radar resolution volume. Given particle size and shape, ice produces a lower $\mathrm{Zh}$ than liquid water, because of the difference in dielectric constant [9].

Differential reflectivity ( $\mathrm{Zdr}$ ) is obtained from the difference of the horizontal reflectivity $(\mathrm{Zh})$ and vertical reflectivity $(\mathrm{Zv})$ and it is related to the mean shape of particles. Large falling raindrops generate positive $Z d r$ values because of their oblate shapes and a preferred orientation [8]. In contrast, hailstones are often more spherical and undergo tumbling. This tends to equalize $\mathrm{Zh}$ and $\mathrm{Zv}$, meaning that hail is isotropic and thus causes the $\mathrm{Zdr}$ value to be near $0 \mathrm{~dB}$ in case of approximately spherical hailstones.

The specific differential phase $(\mathrm{Kdp})$ is the range derivative of the differential phase $(\varphi \mathrm{dp})$ between received horizontally and vertically polarized waves. Kdp is not affected by attenuation and can be used to differentiate between rain and isotropic hydrometeors such as tumbling hail. Kdp is also dependent on the hydrometeor number concentration.

The linear depolarization ratio (LDR) is the ratio between vertically polarized power backscattered for a horizontally polarized transmitted wave (cross-polar power) and co-polar backscattered power. Tumbling, wet non-spherical particles such as hail, melting aggregates and wet graupel can be identified by large LDR values, whereas drizzle and dry ice particles are associated with low LDR values [9]. Due to its technical demands, LDR is not commonly available from Czech radars.

The correlation coefficient $(\rho \mathrm{hv})$ is the correlation between horizontally and vertically polarized echoes. The $\rho$ hv values are close to unity for rain and pure ice crystals. Hail and mixed phase can be detected using low values of $\rho$ hv, because these indicate a variability in the scattering characteristics of precipitation particles for a given size [12].

The Vaisala HydroClass software is a collection of echo identification algorithms and uses the fuzzy logic approach [6]. The essential parts for hydrometeor classification are the MeteoClassifier from CSU [19] and the PrecipClassifier from the National Severe Storm Laboratory (NSSL) [13]. Five final hydrometeor classes comprise the output from the HydroClass: rain, wet snow, dry snow, graupel and hail. The hydrometeor classification system using fuzzy logic, which forms HydroClass, is described in Reference [19]. First, the melting layer is detected as the height parameter or the external melting layer 
height is used. Then, a fuzzification converts the input measurements to fuzzy sets with corresponding membership degree using the Beta function model. The fuzzification is followed by an inference, which is a rule-based procedure to obtain the strength of individual propositions. The weight factors are different regardless of whether the LDR is included or not and the rule strengths were optimized for the C-band radars [6]. The final defuzzification aggregates the rule strength and selects the best representative class. Because of the fact, that the original CSU classifier was developed for use with S-band radar [19], customization for C-band was needed. As Kaltenboeck and Ryzhkov [20] showed, polarimetric radar variables measured in the presence of hail at C-band radar are quite different from those at S-band. Therefore, using data from the Vaisala polarimetric weather radar at the University of Helsinki, new membership functions and rule strength coefficients were found [6,21]. These are used as default settings for the Czech C-band weather radars.

In addition to the hail identified by the HydroClass, another hail parameter is discussed in this study. The hail differential reflectivity (Hdr) was developed by Aydin et al. [22], which uses Zh and $\mathrm{Zdr}$ to distinguish hail from rain. From disdrometer measurements, a simple parametrization was inferred for the rainfall boundary. An expression for this curve is given by:

$$
f(Z d r)=\left\{\begin{array}{c}
27, \text { for } Z d r \leq 0 \\
19 Z d r+27, \text { for } 0 \leq Z d r \leq 1.74 \\
60, \text { for } Z d r>1.74
\end{array},\right.
$$

where $\mathrm{f}(\mathrm{Zdr})$ is in $\mathrm{dB}$. The $\mathrm{Hdr}$ in $\mathrm{dB}$ is then defined as [22]:

$$
\mathrm{Hdr}=\mathrm{Zh}-\mathrm{f}(\mathrm{Zdr})
$$

Positive Hdr values, which result from relatively small Zdr values with large Zh values, signify the presence of hail [8]. Depue et al. [8] examined Hdr as a hail size identifier and found threshold values for large and damaging hail. Specifically, large hail with a diameter larger than $19 \mathrm{~mm}$ is likely when $\mathrm{Hdr} \geq 21 \mathrm{~dB}$ and hail causing damage to residential structures and vehicles is likely when $\mathrm{Hdr}>30 \mathrm{~dB}$. In this study, the performance of Hdr as a hail size identifier is compared with the MEHS hail-size model ability.

\subsection{Hail Reports and Input Data}

A preliminary selection of data for the study was made by using the European Severe Weather Database (ESWD) reports [23]. Five days from May and June 2016 were found with several hail reports that contained enough accompanying information about the time and location of hail occurrence together with the basic information about hailstone size. Based on these dates, the radar data were acquired and specific hail and heavy rain reports were chosen.

Data from the two C-band radars of the Czech radar network CZRAD, Brdy and Skalky, were available [1] for the hail detection. The CZRAD radars are operated by the Czech weather service (Czech Hydro-Meteorological Institute, CHMI) and they were completely replaced with new dual-polarization Doppler weather radars Vaisala WRM-200 in 2015. For calibration of the radars, the original Vaisala methodology and the software tools Vaisala IRIS were used including the attenuation correction. More details about the calibration can be found in Reference [24].

Volume data from the CZRAD radars included the parameters $\mathrm{Zh}, \mathrm{Zdr}, \rho \mathrm{hv}, \varphi \mathrm{dp}, \mathrm{Kdp}$ and HCLASS. The last parameter, HCLASS, designates the report about the HydroClass echo identification. HydroClass covers 5 hydro-meteorological categories along with non-meteorological category. Hail is represented by number 6 in the HCLASS parameter. All the data are available at 12 elevations separately for both radars. However, only the elevation of $0.1^{\circ}$ is used in this comparative study. It is the lowest elevation in the CZRAD scan strategy, which gives the best evidence about the hydrometeors nearest to the Earth's surface. Merged pseudoCAPPI (extended Constant Altitude Plan Position 
Indicator) values of $\mathrm{Zh}$ from 39 levels with $500 \mathrm{~m}$ steps were also available for the COMBI calculation. All the radar data have a spatial resolution of $1 \times 1 \mathrm{~km}$ and a temporal resolution of $5 \mathrm{~min}$.

Atmospheric sounding data were used from the Prague-Libus station, with the data collected at noon on each day.

Ground truth data about the hail events were taken from the ESWD reports [23]. The ESWD reports include information about location, time of occurrence, reporting status (the quality check level), maximum or mean hail size and possibly some other supplementary information about the reported event [25]. The information about the time occurrence includes the time span reflecting a possible uncertainty in the time determination (time uncertainty).

Large hail reports with quality levels QC1 (report confirmed) and QC2 (event fully verified) and with the time uncertainty of 15 min or less were taken into account. To avoid duplicate entries reporting the same hail event, only the entry with the lowest time uncertainty was selected from the reports with less than $5 \mathrm{~min}$ temporal distance and less than $10 \mathrm{~km}$ spatial distance, in accordance with [26]. In total, 27 reports were included in the study using these rules and preselected radar data (Table 1). There are events from 13 localities on 23 May, from 5 localities on 28 May, from two localities on 31 June, from three localities on 16 June and from three localities on 25 June in the Table 1. According to the ESWD information about the hail size, 6 events were determined as damaging (Table 1 in bold). It means that the events with reported hailstones up to $4 \mathrm{~cm}$ in diameter or more were taken as damaging at the hail size comparison. The $4 \mathrm{~cm}$ threshold agrees with the Torro hailstorm intensity scale classification, where hailstones greater than or equal to $3 \mathrm{~cm}$ in diameter (H5) are classified as destructive [27].

All the hail events occurred inside the radar's Brdy range. Only events 18 and 19 were located on the edge of the radar's Brdy range. For the calculations, data from the radar which is closer to an event are used. Therefore, most of the radar data are from the Brdy radar.

Table 1. Hail events included in this study as reported by the ESWD in 2016; destructive events with reported hailstones over $3 \mathrm{~cm}$ in diameter are marked in bold.

\begin{tabular}{|c|c|c|c|}
\hline Nr. & Date, Time (UTC) & Location & Size Information \\
\hline 1 & 23.5. $12: 50$ & Lnáře & \\
\hline 2 & 23.5. $13: 05$ & Strakonice & Larger amount of hailstones up to $2 \mathrm{~cm}$ \\
\hline 3 & 23.5. 13:50 & Březnice & Hailstones up to $4 \mathrm{~cm}$ \\
\hline 4 & 23.5. $14: 15$ & Příbram & Hailstones up to $3 \mathrm{~cm}$ \\
\hline 5 & 23.5. $14: 30$ & Hořovice & Large amount of smaller hailstones \\
\hline 6 & 23.5. $14: 40$ & Soběslav & Hailstones up to $3 \mathrm{~cm}$ \\
\hline 7 & 23.5. $15: 20$ & Bratronice & Hailstones up to $2 \mathrm{~cm}$, large amount \\
\hline 8 & 23.5. $15: 45$ & Čestice & \\
\hline 9 & 23.5. $16: 40$ & Libochovice & Average diameter of hailstones $2 \mathrm{~cm}$ \\
\hline 10 & 23.5. $17: 10$ & Ludvíkovice & Continuous hail cover \\
\hline 11 & 23.5. $17: 35$ & Verneřice & Large amount of hailstones up to $2.5 \mathrm{~cm}$ \\
\hline 12 & 23.5. 18:00 & Jetřichovice & Hailstones up to $4 \mathrm{~cm}$ \\
\hline 13 & 23.5. 18:15 & Krásná Lípa & Hailstones up to $4 \mathrm{~cm}$ \\
\hline 14 & 28.5. 13:00 & Žebnice & Hailstones up to $5 \mathrm{~cm}$, damaged cars, greenhouses \\
\hline 15 & 28.5. $13: 05$ & České Budějovice & Hailstones up to $3 \mathrm{~cm}$ \\
\hline 16 & 28.5. $13: 10$ & Hadačka & Large amount of smaller hailstones \\
\hline 17 & 28.5. $13: 40$ & Bujesily & Hailstones up to $3 \mathrm{~cm}$ \\
\hline 18 & 28.5. $14: 20$ & Očelice & Large amount of hailstones up to $3 \mathrm{~cm}$, trees defoliated \\
\hline 19 & 28.5. $14: 30$ & Olšany & Hailstones up to $3 \mathrm{~cm}$, damage to crops and greenhouse \\
\hline 20 & 31.5. $12: 55$ & Prague-Točná & Hailstones up to $2 \mathrm{~cm}$ \\
\hline 21 & 31.5. $13: 30$ & Prague-Suchdol & Hailstones up to $4 \mathrm{~cm}$ \\
\hline 22 & 16.6. $16: 45$ & Přibram & Large amount of hailstones up to $2 \mathrm{~cm}$ \\
\hline 23 & 16.6. $17: 40$ & Merklín & Hailstones up to $2 \mathrm{~cm}$ \\
\hline 24 & 16.6. $18: 00$ & Strakonice & Large amount of hailstones up to $3 \mathrm{~cm}$ \\
\hline 25 & 25.6. 13:30 & Viteň & Hailstones up to $5 \mathrm{~cm}$ \\
\hline 26 & 25.6. $13: 45$ & Dolní Chabry & Large amount of hailstones up to $2.5 \mathrm{~cm}$ \\
\hline 27 & 25.6. $20: 25$ & Žd'ár & Large amount of hailstones up to $2 \mathrm{~cm}$ \\
\hline
\end{tabular}

To compare radar based parameters of hailstorms with the parameters of heavy convective precipitation without hail, the reports of 21 events with heavy rain were found in the ESWD (Table 2). 
There are events from 11 localities on 23 May, from one locality on 28 May and 9 events from 25 June in Table 2. Checking the ESWD, we recognize that when heavy rain from our selection is reported, no hail is reported at the same time and location. We therefore presume that no significant hail occurred at the same time and location as the heavy rain events included in this study.

Table 2. Heavy rain events included in this study as reported by the European Severe Weather Database (ESWD) in 2016.

\begin{tabular}{|c|c|c|c|c|c|}
\hline Nr. & Date, Time (UTC) & Location & Nr. & Date, Time (UTC) & Location \\
\hline 1 & 23.5. $13: 50$ & Míšov & 12 & 28.5. $13: 20$ & Šindelová \\
\hline 2 & 23.5. $14: 20$ & Konstantinovy Lázně & 13 & 25.6. $13: 20$ & Hejnice \\
\hline 3 & 23.5. $15: 10$ & Strašice & 14 & 25.6. $15: 40$ & Byňov \\
\hline 4 & 23.5. $15: 30$ & Husinec & 15 & 25.6. $20: 20$ & Staňkov \\
\hline 5 & 23.5. $16: 30$ & Zlonice & 16 & 25.6. $20: 30$ & Prášily \\
\hline 6 & 23.5. $16: 30$ & Radošice & 17 & 25.6. $20: 50$ & Stříbro \\
\hline 7 & 23.5. $17: 00$ & Mrtník u Hořovic & 18 & 25.6. $21: 20$ & Brandýs nad Labem \\
\hline 8 & 23.5. $17: 50$ & Verneřice & 19 & 25.6. $21: 20$ & Rokycany \\
\hline 9 & 23.5. $18: 00$ & Benešov nad Ploučnicí & 20 & 25.6. $22: 10$ & Úlice \\
\hline 10 & 23.5. $18: 10$ & Děčín & 21 & 25.6. 23:00 & Děčínský Sněžník \\
\hline 11 & 23.5. $18: 30$ & Střekov & & & \\
\hline
\end{tabular}

The five days selected for this study showed intensive convective activity. Several robust hail reports are included in the ESWD for each of them. Furthermore, several heavy rain events-labeled as convective in the ESWD-occurred during these days. The locations of all the considered hail and heavy rain events are indicated in Figure 1. The synoptic situation during the five days was classified as the pressure through over central Europe or as a low-pressure situation. Specifically, the severe hailstorms on 23 May 2016 produced damaging hail at several Czech locations including Prague, see Figure 2. From the early afternoon onward, two supercells developed in Southern Bohemia and travelled in parallel to the north along both sides of the Brdy range. This process is reflected by the form of two parallel hailswaths. The hailswaths merged near the town of Slaný after 4 hours at a distance of approximately $100 \mathrm{~km}$. Figure 2 also shows that several separate hailstorms occurred in northern and southern Bohemia during the afternoon. Some of them were spatially separated from the main structure (e.g., event 6), some of them were inside the space structure but separated in the time of occurrence (e.g., event 8).

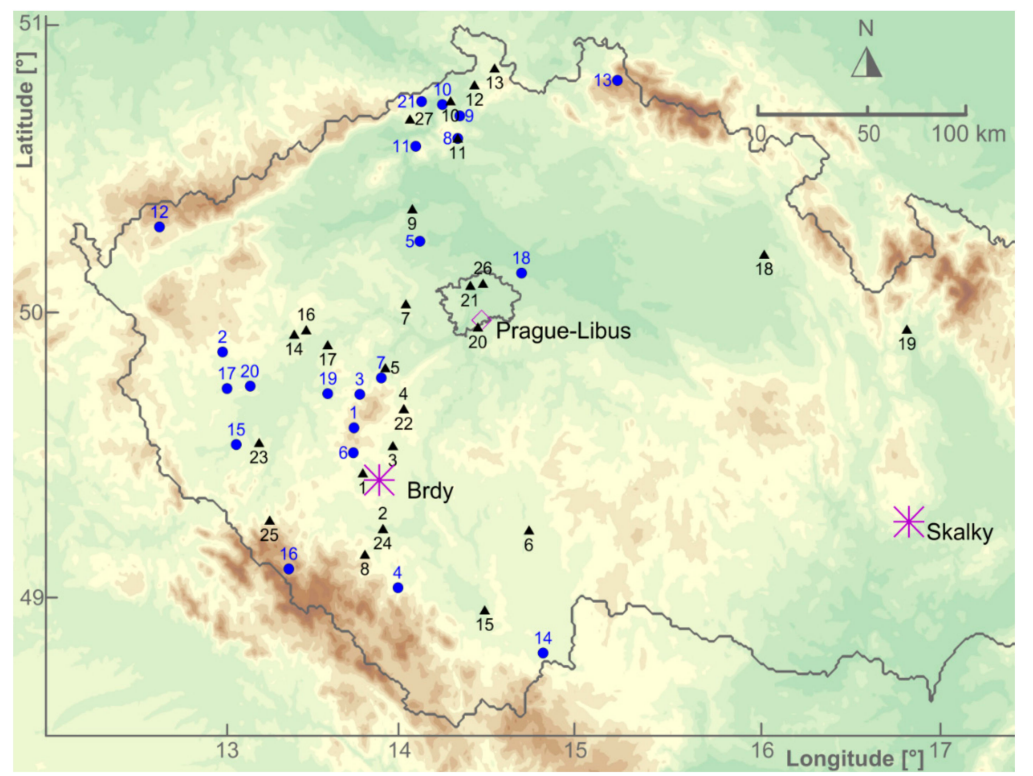

Figure 1. Location of 27 hail events (black triangles) and 21 heavy rain events (blue circles) with positions of the two Czech radars (violet asterisks). For the date and time of occurrence see Tables 1 and 2. 


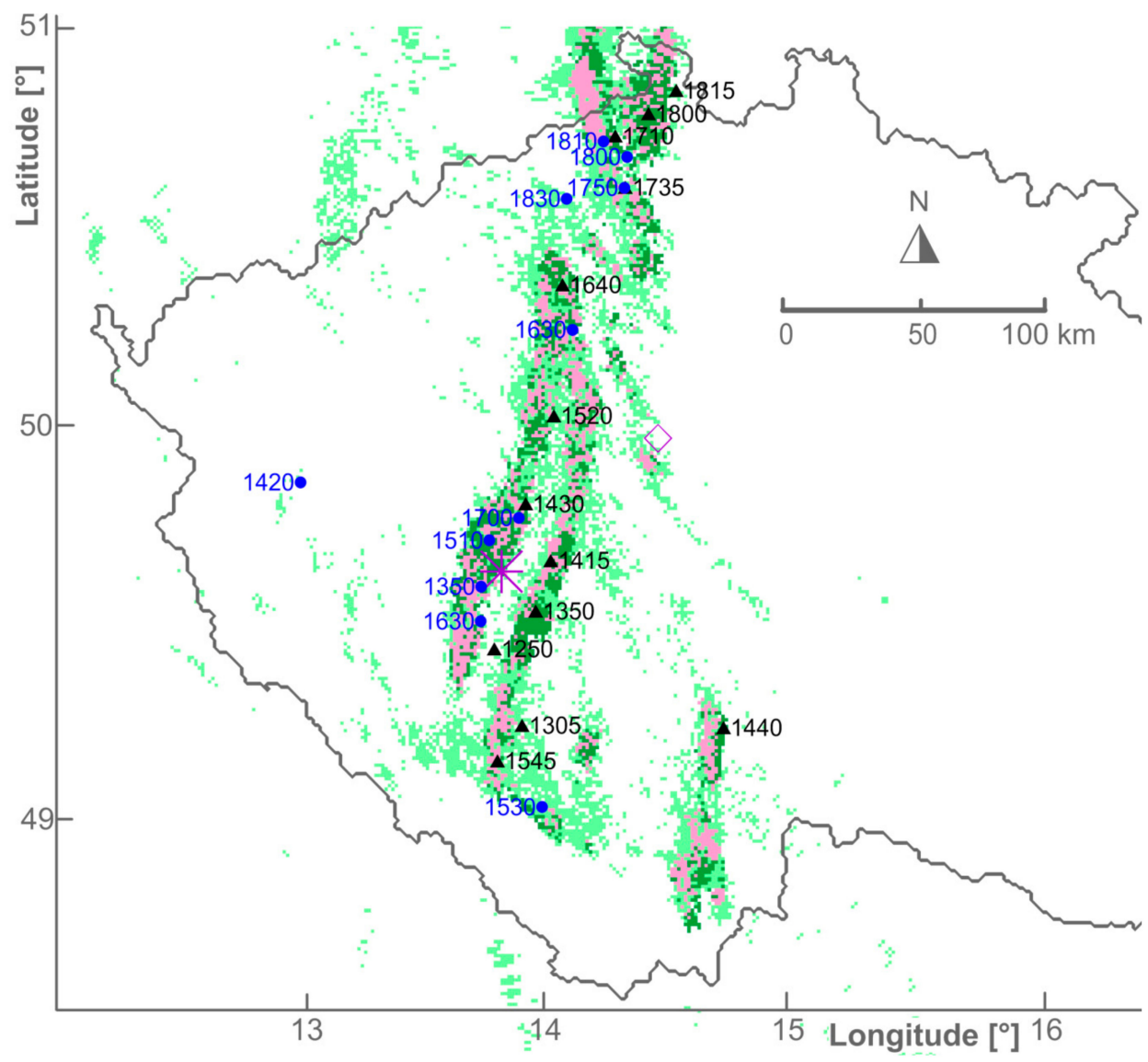

Figure 2. Hail detection for 23 May 2016. Hail reports (black triangles) and heavy rain reports (blue circles) from the ESWD with the time of occurrence (see Tables 1 and 2) and hail detected with HydroClass and COMBI. A pink color shows hail detected both by COMBI and HydroClass; light green-hail detected by HydroClass only; dark green—hail detected by COMBI only. Positions are indicated for the radar Brdy (violet asterisk) and the sounding station Praha-Libuš (violet diamond).

\section{Results and Discussion}

\subsection{Hail Detection Results}

To achieve the main objective of this study, that is, comparing radar-based hail detections via single- and dual-polarization data, we worked with hail events that occurred over the territory of Czechia in 2016. To be consistent with time and space uncertainty included in the ESWD hail reports, we represent the hail event occurrence by the radar information from a time and space window. The time window of $30 \mathrm{~min}$ is selected because of the $15 \mathrm{~min}$ maximum uncertainty period in the ESWD reports. The selected space window of $15 \mathrm{~km} \times 15 \mathrm{~km}$ corresponds to the typical storm cell velocity. If we assume that the storm cell velocity is $27 \mathrm{~km} / \mathrm{h}$ [28], then the covered distance is approximately $14 \mathrm{~km}$. For each hail or rain event the space window covers 225 radar pixels, which gives 1350 pixels during the time window of $30 \mathrm{~min}$.

The hail detection methodologies applied in the COMBI and HydroClass are fundamentally different. The single-polarization COMBI criterion estimates hail occurrence on the basis of storm structure and other properties of convective environment [5]. In contrast, the polarimetric HydroClass classification determines the regions of hail category on the basis of the difference between polarization properties of different hydrometeors [16]. There is also the dissimilarity in the possible radar data artefacts affecting the hail detection methods in our study. Whereas the COMBI criterion uses volume radar data, only the HydroClass results from the lowest radar elevation were considered. These may be affected by the artefacts connected with the removal of wi-fi interference over the Czech territory 
(Novak, CHMI, personal communication). Nevertheless, the differences in detection results are not very substantial and general patterns of hail detection correspond to each other in time and space. It is shown by the hail detection capability of both methods as is illustrated in Figure 2 for the whole 23 May 2016. We observe a nearly identical space structure of the hail pixels as indicated by both techniques.

We were interested in the extent of hail detection using the techniques COMBI and HydroClass. Therefore, the numbers of pixels with detected hail were determined and they are shown in Figure 3 for all 27 hail events. In all events, hail was detected in corresponding space $x$ time windows both by the COMBI criterion and HydroClass algorithm. Generally, the hail pixel numbers are comparable for both methods. Figure 3 shows that hail was detected by both the COMBI criterion and the HydroClass algorithm during all 27 events. However, the pixel numbers where both COMBI and HydroClass (the green columns in Figure 3) detected hail are smaller than the numbers corresponding to either COMBI or HydroClass individually (the blue and red columns in Figure 3).

COMBI detects a larger number of pixels than HydroClass in 19 events while for the other 8 events the opposite is true. A larger number of pixels detected as hail pixels does not imply a better quality of detection technique. We have to take into account that the ESWD verification data contain only general information about the hail event. In contrast to the study [16], the ESWD verification data do not contain any information about the time and place structure of the hail occurrence. Therefore, the ESWD information does not allow any false alarm identification. We do not know where the hail did not occur inside the space $x$ time window. It is a significant difference of the JPOLE study [16]. The smaller number of pixels where both the methods detected hail simultaneously in comparison with separate detections agrees with the fact, that the techniques COMBI and HydroClass fundamentally differ.

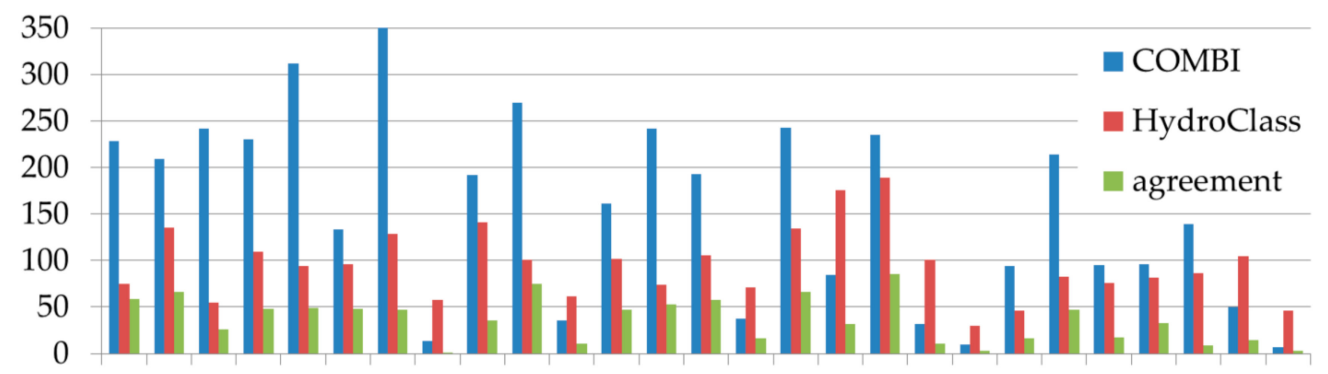

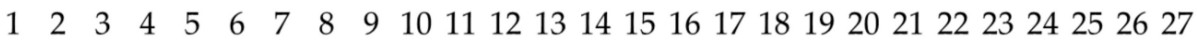

Figure 3. Sum of pixels where COMBI detects hail (blue), HydroClass classifies hail (red) and where both COMBI and HydroClass detect hail (green). For each ESWD hail event, in total 1350 pixels are considered from a space $\mathrm{x}$ time window (see the text for the window definition).

For comparison, we also considered the pixel numbers with a column maximum horizontal reflectivity $\mathrm{Zh}$ of at least $55 \mathrm{dBZ}$ and a hail differential reflectivity Hdr of at least $21 \mathrm{~dB}$. Such high reflectivity values (maximum or differential) were observed in the windows at all hail events.

We were interested in the differences of values of individual polarimetric variables measured in the pixels when COMBI detects hail and/or when HydroClass classifies hail. Several basic statistics, which represent the distribution of radar variable values, are presented in Table 3 for cases when hail was detected by only COMBI or HydroClass. Table 3 indicates that the differences in the statistics of polarimetric variables are not large and we could not identify substantial differences between the COMBI and HydroClass columns. 
Table 3. The statistics of observed variable values $\mathrm{Zdr}, \rho \mathrm{HV}, \mathrm{Kdp}, \varphi \mathrm{dp}$ and maximum $\mathrm{Zh}$ for the pixels with (a) hail detected by COMBI but not by HydroClass (COMBI columns) and (b) classified as hail by HydroClass but not by COMBI (HC columns).

\begin{tabular}{ccccccccccc}
\hline \multirow{2}{*}{ Statistics } & \multicolumn{2}{c}{ Zdr [dB] } & \multicolumn{2}{c}{$\boldsymbol{\rho H V}$} & \multicolumn{2}{c}{ Kdp [deg/km] } & \multicolumn{2}{c}{$\boldsymbol{\rho d p}[\mathrm{deg}]$} & \multicolumn{2}{c}{ maxZh [dBZ] } \\
\cline { 2 - 11 } & COMBI & HC & COMBI & HC & COMBI & HC & COMBI & HC & COMBI & HC \\
\hline max & 7.9 & 7.9 & 1.0 & 1.0 & 10.0 & 10.0 & 177.2 & 170.1 & 66.0 & 70.0 \\
min & -7.9 & -5.9 & 0.1 & 0.6 & -2.1 & -2.6 & 1.4 & 20.6 & 48.5 & 42.0 \\
mean & 0.1 & 3.0 & 0.8 & 0.9 & 1.0 & 1.6 & 70.0 & 66.2 & 57.2 & 54.2 \\
median & 0.3 & 3.4 & 0.9 & 0.9 & 0.4 & 1.2 & 62.4 & 61.7 & 57.0 & 54.0 \\
10th percentile & -4.6 & -0.6 & 0.7 & 0.9 & -0.5 & -0.1 & 37.6 & 44.7 & 54.0 & 48.0 \\
90th percentile & 4.7 & 6.2 & 1.0 & 1.0 & 3.2 & 3.9 & 112.7 & 94.3 & 60.5 & 60.0 \\
\hline
\end{tabular}

The results in Table 3 are very similar for both methods, except Zdr. Obviously, the maximum Zdr value both at COMBI and HydroClass corresponds to the maximum given by Vaisala radars, as does the minimum $\mathrm{Zdr}$ value at the COMBI. The higher minimum value at the HydroClass possibly relates to the HydroClass setting and needs future investigation.

It is almost impossible to obtain information about false alarms linked with the hail detection. In order to get information about how the HydroClass and COMBI work at precipitation events without reported hail occurrence, both hail detection techniques were applied to data from heavy rain events (Figure 4). From the 21 events, hail pixels were identified in 6 events by both methods. From those 6 events with positive hail detection, the HydroClass identified a larger number of hail pixels than identified by COMBI in 4 cases. In the next 6 cases, when only the HydroClass detected hail, the 4 cases can be marked as trace detection (events 2, 7,15 and 17) with less than 5 hail pixels. Only two events show a low number of hail pixels erroneously classified only by the HydroClass. These are events 10 and 13 with 20 and 33 hail pixels, respectively. Both events ocurred at a large distance of more than $100 \mathrm{~km}$ from the radar (see Figure 1).

The numbers of pixels with detected hail inside the space $x$ time windows with heavy rain reports seem to indicate the false alarm quantity but we have to take into account the uncertainty about the possible presence of hail in the windows. Considering the total number of 1350 pixels in one time $x$ space window, the numbers of pixel with detected hail are comparable for both techniques. Generally, we take the agreement in results between the HydroClass and COMBI hail detection methods as convincing. There is only a weak enhancement in the number of hail pixels during a false HydroClass classification. Similar to events 10 and 13, events 8, 9 and 14 with the prevailing HydroClass classification belong to those distant from the radar position.

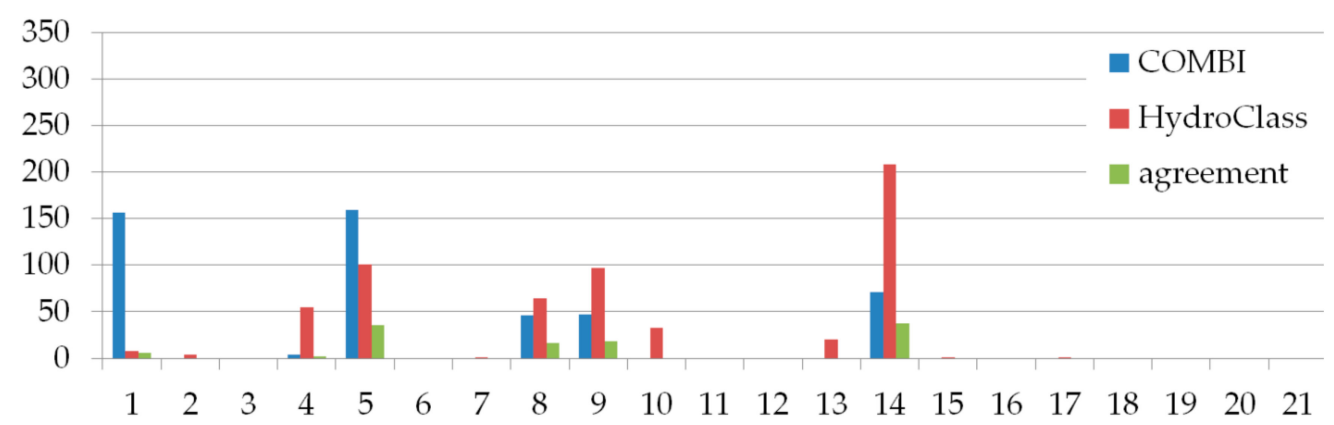

Figure 4. The same as Figure 3 but for 21 ESWD events classified as heavy rain events (Table 2).

It is hardly possible to judge whether the polarimetric HydroClass is so significantly better than COMBI like the result in Reference [16] showing the better HCA compared to HDA. Firstly, the COMBI and the HDA differ in their principles and application. Secondly, the verification data, used in this study, do not allow to characterize the internal structure of the events. More detailed comparison would be possible by the reduction of the time $\mathrm{x}$ space window. However, more hail events will be 
suitable for a proper statistical evaluation. In every case, the operative use of HydroClass is useful also because of easier application without comparatively complex calculation of COMBI.

\subsection{Comparing Hail Size Detection}

The ESWD reports include information about hailstone size, which mostly regards the maximum hailstone size registered during the event. Such information allows us to examine the performance of hail size detection from the radar data and compare the methods using MEHS, based on single-polarization data and Hdr, based on the dual-polarization data.

The MEHS capability for hail size identification was proven by Brimelow and Taylor [29], see Equation (1). For each hail event and heavy rain event, we computed maximum MEHS value in the time and space window.

Depue et al. [8] used Hdr as the hail size identifier, see equation (3). We also computed maximum Hdr for all the hail and heavy rain events. In the scatterplot (Figure 5), hail and heavy rain events are depicted in the MEHS and Hdr plane.

All the hail events reach the MEHS values over 10, which indicate a hail size of more than $1 \mathrm{~cm}$ in diameter. For most of the hail events MEHS values exceed the $2 \mathrm{~cm}$ size boundary. The MEHS values are in accordance with the events reporting severe hail. Events 3, 12, 13, 14, 21 and 25 (Table 1), which were identified as damaging in the ESWD, are marked in red (Figure 5). The MEHS values detected these events via recording a maximum diameter of over $2 \mathrm{~cm}$. Only four from the heavy rain events are in the range of MEHS values that indicate hail with a diameter over $1 \mathrm{~cm}$. Three others correspond to small and not damaging hailstones and all remaining rain events do not show any hail.

For Hdr values, the $21 \mathrm{~dB}$ threshold should indicate hail and, the value $30 \mathrm{~dB}$ large hailstones. Most of the hail events occurred where the Hdr is above $21 \mathrm{~dB}$ together with six heavy rain events. We even found two heavy rain events in the range of $\mathrm{Hdr}>30 \mathrm{~dB}$.

In general, both the single- and dual-polarization based methods detected dangerous hail events. However, for both MEHS and Hdr criteria, large hail events with a diameter reaching $4 \mathrm{~cm}$ and above are difficult to distinguish from the events with reported smaller hailstones. Nevertheless, both the MEHS and Hdr were developed by using S-band radars [7,22] and we tested their abilities without any adjustment to the $\mathrm{C}$-band radars, which are used in this study.

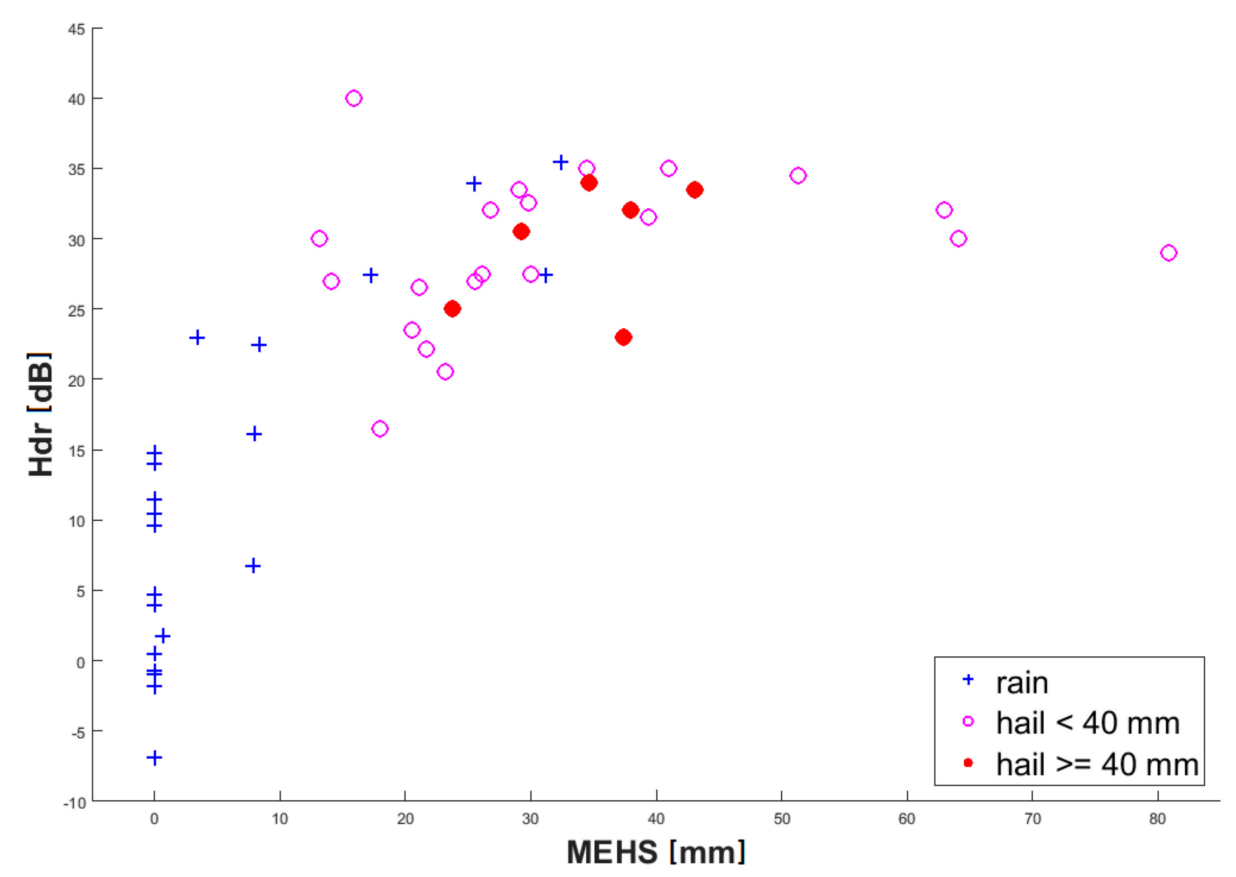

Figure 5. Scatterplot of hail events (empty or full red circles) and heavy rain events (blue crosses) in the hail differential reflectivity (Hdr) and Maximum Expected Hail Size (MEHS) plane. 


\section{Conclusions}

We analyzed hail and heavy rain events from ESWD database to compare hail detection performance based on single- and dual-polarization radar data. Hail detection based on single-polarization used the COMBI index developed by Skripnikova and Rezacova [5]. The hail detection with dual-polarization data used the HydroClass technique [6]. In total, 27 hail events from summer 2016 were identified in the ESWD data and were used for the detection tests. For comparison and for an evaluation of false alarm possibilities, we found 21 heavy rain events in the ESWD database. All the hail and heavy rain events occurred over Czech territory in 2016.

The comparison showed that both techniques can detect hail with a very similar efficiency. Both the COMBI criterion and the HydroClass detected hail during all the studied hail events. Generally, more pixels were detected by the COMBI criterion as hail. It does not mean that the COMBI is better in hail detection than the polarimetric HydroClass, as the general ESWD information about the hail events does not allow any false alarm identification.

Both techniques showed a nearly identical spatial structure for the hail pixels during the 23 May 2016 hail day. We examined the range of individual polarimetric variables for the COMBI or HydroClass methods based on their detection of hail. Even in using this comparison, the differences were not overly distinct. The heavy rain events were tested for false hail detection using both COMBI and HydroClass criteria. The total number of hail pixels detected was higher when using COMBI but was still very similar to HydroClass. From the 21 heavy rain events, in 6 of them hail was detected by both methods. The HydroClass classified hail during 6 other heavy rain events but only in trace amounts.

The hail size detection was studied by using single-polarization MEHS and dual-polarization Hdr techniques. Both techniques showed the ability to detect and classify large hailstones. Conversely, both techniques failed in distinguishing large damaging hailstones reported in ESWD with diameters reaching $4 \mathrm{~cm}$ or more from the events with the smaller hailstones.

Both techniques, COMBI and HydroClass, differ fundamentally. The HydroClass technique is a general method, which aims at the classification of various hydrometeor types by using the set of polarization variables. We used the Vaisala HydroClass results without any adjustment of HydroClass parameters. On the other hand, the COMBI was developed specifically for hail detection only and tested with a set of European more or less local hail events. The 27 hail events in this study are independent of the test events from the first study [5]. This study showed that both the COMBI criterion and the HydroClass algorithm produce hail detection rates that are in accordance with the ESWD hail reports on the ground in time and space. The detection extents are similar for the both methods.

It is difficult to judge why the polarimetric HydroClass is not significantly better than COMBI as with the result showing better HCA performance compared to HDA in Reference [16]. Firstly, the COMBI and the HDA differ in their principles. Secondly, used verification data do not allow characterization of the internal structure of the events. In any case the operative application of HydroClass is easier than the calculation of COMBI.

A possible motivation for future is to increase the number of hail events in order to study the effect of time and place of hail detection occurrence in more detail. For example, the larger sample of data can improve the statistical analysis of the effect of various space and time windows and so forth.

Author Contributions: K.S. conducted the literature review, tested the algorithms, processed results graphically and wrote the majority of the manuscript; D. ̌̌. conceived the paper and partly wrote the manuscript.

Funding: This research received external additional funding from the Czech academy of sciences in the project L100421701.

Acknowledgments: The authors acknowledge the Postdoc support project L100421701 and the IAP institutional support RVO: 68378289. The radar data were kindly provided by the Czech Hydrometeorological Institute and the ESWD reports were used.

Conflicts of Interest: The authors declare no conflict of interest. The funders had no role in the design of the study; in the collection, analyses or interpretation of data; in the writing of the manuscript or in the decision to publish the results. 


\section{References}

1. Novák, P.; Kyznarová, H. Upgrade of the CZRAD meteorological radar network in 2015. Meteorol. Bull. 2016, $69,17-24$.

2. Germann, U.; Boscacci, M.; Gabella, M.; Sartori, M. Radar design for prediction in the Swiss Alps. Meteorol. Technol. Int. 2015, 4, 42-45.

3. ̌ezáčová, D.; Szintai, B.; Jakubiak, D.; Yano, J.-I.; Turner, S. Verification of High-Resolution Precipitation Forecast with Radar-Based Data. In Parameterization of Atmospheric Convection (In 2 Volumes): Volume 1: Theoretical Background and Formulation; Volume 2: Current Issues and New Theories; Series on the Science of Climate Change; Imperial College Press: London, UK, 2015; Volume 1, pp. 173-214, ISBN 978-1-78326-690-6.

4. Bringi, V.N.; Seliga, T.A.; Aydin, K. Hail Detection with a Differential Reflectivity Radar. Science 1984, 225, 1145-1147. [CrossRef] [PubMed]

5. Skripniková, K.; Řezáčová, D. Radar-based hail detection. Atmos. Res. 2014, 144, 175-185. [CrossRef]

6. Dual Polarization IRIS and RDA User Guide. Available online: Ftp://ftp.sigmet.com/outgoing/manuals/IRIS_ and_RDA_Dual_Polarization_Users_Manual.pdf (accessed on 29 May 2018).

7. Witt, A.; Eilts, M.D.; Stumpf, G.J.; Mitchell, E.D.W.; Johnson, J.T.; Thomas, K.W. Evaluating the Performance of WSR-88D Severe Storm Detection Algorithms. Weather Forecast. 1998, 13, 513-518. [CrossRef]

8. Depue, T.K.; Kennedy, P.C.; Rutledge, S.A. Performance of the Hail Differential Reflectivity $\left(H_{\mathrm{DR}}\right)$ Polarimetric Radar Hail Indicator. J. Appl. Meteorol. Climatol. 2007, 46, 1290-1301. [CrossRef]

9. Chandrasekar, V.; Keränen, R.; Lim, S.; Moisseev, D. Recent advances in classification of observations from dual polarization weather radars. Atmos. Res. 2013, 119, 97-111. [CrossRef]

10. Straka, J.M.; Zrnic, D.S. An Algorithm to Deduce Hydrometeor Types and Contents from Multiparameter Radar Data; American Meteor Society: Norman, OK, USA, 1993.

11. Höller, H.; Hagen, M.; Meischner, P.F.; Bringi, V.N.; Hubbert, J. Life Cycle and Precipitation Formation in a Hybrid-Type Hailstorm Revealed by Polarimetric and Doppler Radar Measurements. J. Atmos. Sci. 1994, 51, 2500-2522. [CrossRef]

12. Vivekanandan, J.; Ellis, S.M.; Oye, R.; Zrnic, D.S.; Ryzhkov, A.V.; Straka, J. Cloud Microphysics Retrieval Using S-band Dual-Polarization Radar Measurements. Bull. Am. Meteorol. Soc. 1999, 80, 381-388. [CrossRef]

13. Straka, J.M.; Zrnić, D.S.; Ryzhkov, A.V. Bulk Hydrometeor Classification and Quantification Using Polarimetric Radar Data: Synthesis of Relations. J. Appl. Meteorol. 2000, 39, 1341-1372. [CrossRef]

14. Haykin, S. Cognitive radar: A way of the future. IEEE Signal Process. Mag. 2006, 23, 30-40. [CrossRef]

15. Liu, H.; Chandrasekar, V. Classification of Hydrometeors Based on Polarimetric Radar Measurements: Development of Fuzzy Logic and Neuro-Fuzzy Systems and In Situ Verification. J. Atmos. Ocean. Technol. 2000, 17, 140-164. [CrossRef]

16. Ryzhkov, A.V.; Schuur, T.J.; Burgess, D.W.; Heinselman, P.L.; Giangrande, S.E.; Zrnic, D.S. The Joint Polarization Experiment: Polarimetric Rainfall Measurements and Hydrometeor Classification. Bull. Am. Meteorol. Soc. 2005, 86, 809-824. [CrossRef]

17. Ortega, K.L.; Krause, J.M.; Ryzhkov, A.V. Polarimetric Radar Characteristics of Melting Hail. Part III: Validation of the Algorithm for Hail Size Discrimination. J. Appl. Meteorol. Climatol. 2016, 55, 829-848. [CrossRef]

18. Waldvogel, A.; Federer, B.; Grimm, P. Criteria for the Detection of Hail Cells. J. Appl. Meteorol. 1979, 18, 1521-1525. [CrossRef]

19. Lim, S.; Chandrasekar, V.; Bringi, V.N. Hydrometeor classification system using dual-polarization radar measurements: Model improvements and in situ verification. IEEE Trans. Geosci. Remote Sens. 2005, 43, 792-801. [CrossRef]

20. Kaltenboeck, R.; Ryzhkov, A. Comparison of polarimetric signatures of hail at $\mathrm{S}$ and $\mathrm{C}$ bands for different hail sizes. Atmos. Res. 2013, 123, 323-336. [CrossRef]

21. Puhakka, T.; Leskinen, M.; Puhakka, P.; Niemi, S.; Konkola, L.; Tollman, N. University of Helsinki research radar setup. In Proceedings of the 4th European Conference on Radar Meteorology and Hydrology, Barcelona, Spain, 18-22 September 2006.

22. Aydin, K.; Seliga, T.A.; Balaji, V. Remote Sensing of Hail with a Dual Linear Polarization Radar. J. Clim. Appl. Meteorol. 1986, 25, 1475-1484. [CrossRef] 
23. Dotzek, N.; Groenemeijer, P.; Feuerstein, B.; Holzer, A.M. Overview of ESSL's severe convective storms research using the European Severe Weather Database ESWD. Atmos. Res. 2009, 93, 575-586. [CrossRef]

24. Novák, P. Overview of the Czech Weather Radar Network-Calibration and monitoring. In Proceedings of the Weather Radar Calibration \& Monitoring workshop (WXRCalMon), Offenbach, Germany, 18-20 October 2017.

25. ESWD Event Reporting Criteria. Available online: https://www.essl.org/cms/wp-content/uploads/20140509ESWD_criteria.pdf (accessed on 31 January 2017).

26. Wapler, K. The life-cycle of hailstorms: Lightning, radar reflectivity and rotation characteristics. Atmos. Res. 2017, 193, 60-72. [CrossRef]

27. Webb, J.D.C.; Elsom, D.M.; Meaden, G.T. TheTORRO hailstorm intensity scale. J. Meteorol. 1986, 11, 337-339.

28. Počakal, D.; Večenaj, Ž.; Štalec, J. Hail characteristics of different regions in continental part of Croatia based on influence of orography. Atmos. Res. 2009, 93, 516-525. [CrossRef]

29. Brimelow, J.C.; Taylor, N.M. Verification of the MESH Product over the Canadian Prairies Using a High-Quality Surface Hail Report Database Sourced from Social Media. Available online: https:/ams.confex.com/ams/ 38RADAR/meetingapp.cgi/Session/44003 (accessed on 20 November 2018).

(C) 2019 by the authors. Licensee MDPI, Basel, Switzerland. This article is an open access article distributed under the terms and conditions of the Creative Commons Attribution (CC BY) license (http://creativecommons.org/licenses/by/4.0/). 